\title{
Notes
}

\section{Geophysical constraints on the thickness of the Holyrood Pluton, Avalon Peninsula, Newfoundland}

\author{
H.G. Miller and D.A. Pittman* \\ Earth Sciences Department \\ Memorial University of Newfoundland, St. John's, Newfoundland \\ * now at Petro Canada, P.0. Box 2844, Calgary, Alberta
}

\begin{abstract}
The vertical extent of the Holyrood Pluton and the surrounding Harbpur Main Group of the northeastern Avalon Peninsula of Newfoundland is estimated using two-dimensional gravity and magnetic models. The models are interpreted to indicate that the maximum thickness of the Holyrood Pluton is $1.8 \mathrm{~km}$ and that mafic Harbour Main volcanics must exist beneath the pluton and be confined to the upper $2.0 \mathrm{~km}$ of the crust west of the Conception/Cabot Group boundary on the eastern portion of the survey area.

En utilisant des modèles à deux dimensions de gravité et de magnétisme, on a estimé l'étendue verticale du pluton Holyrood et du groupe circonvoisin de Harbour Main dans l'est de la péninsule Avalon, Terre-Neuve. L'interprétation des modèles indique que lépaisseur maximale du pluton Holyrood atteint $1.8 \mathrm{~km}$ et que des roches volcaniques mafiques du groupe Harbour Main doivent se trouver sous le pluton et restreintes aux $2.0 \mathrm{~km}$ supérieurs de l'écorce se trouvant à l'ouest de la limite des groupes de Conception et de Cabot, dans la partie orientale de la région étudiée.
\end{abstract}

[Traduit par le journal]

\section{INTRODUCTION}

This note reports a geophysical determination of the thickness of the Holyrood Pluton of eastern Newfoundland using gravity data collected by one of us (DAP), and aeromagnetic data from the G.S.C. aeromagnetic map for the area.

The Holyrood pluton has been investigated geochemically by Strong and Minatides (1975) who note the presence of a positive gravity anomaly in the vicinity of the pluton and comment that it may be due to either the basaltic rocks of the Harbour Main Group or to a hornblende-rich gabbro phase of the pluton. They also note that no geophysical evidence has been presented for the existence of 'continental' basement beneath the Harbour Main. A secondary objective of this note is therefore to deduce what underlies the pluton. Before any interpretation can be undertaken the geological setting of the pluton must be comprehended.

\section{GEOLOGICAL SETTING}

The Holyrood Pluton is a granitic pluton approximately thirty kilometers

MARITIME SEDIMENTS AND ATLANTIC GEOLOGY $18,75-82(1982)$ long and ten kilometers wide situated in the central portion of the eastern Avalon Peninsula of Newfoundland (Fig. 1). It consists of typically massive pale pink granite with markedly smaller fringing stocks and marginal bodies of quartz-monzonite and even smaller marginal or overlying bodies of quartz hornblende gabbro having sharp intrusive relationships with the adjacent volcanic rocks of the Harbour Main Group. (McCartney 1967; Hughes and Bruckner 1971). McCartney, on the basis of the observed field relationships, considers the granite to be a single intrusion post dating the Harbour Main Group into which it is intruded. The granitic portion of the pluton has been dated at $574 \pm 11 \mathrm{Ma}$ using $\mathrm{Rb}-\mathrm{Sr}$ methods $(607 \pm 11$ Ma using $\left.\lambda^{27} \mathrm{Rb}=1.39 \times 10^{-11} \mathrm{yr}\right) \quad(\mathrm{Mc}-$ Cartney 1967). Hughes and Brückner consider the intrusion to be approximately contemporaneous with the surrounding Harbour Main volcanics and the sediments of the Conception Group.

The pluton is surrounded by the Harbour Main Group volcanic rocks which range in composition from rhyolites immediately to the west of the pluton to mafic and acidic volcanics outcropping at several localities along the fault 


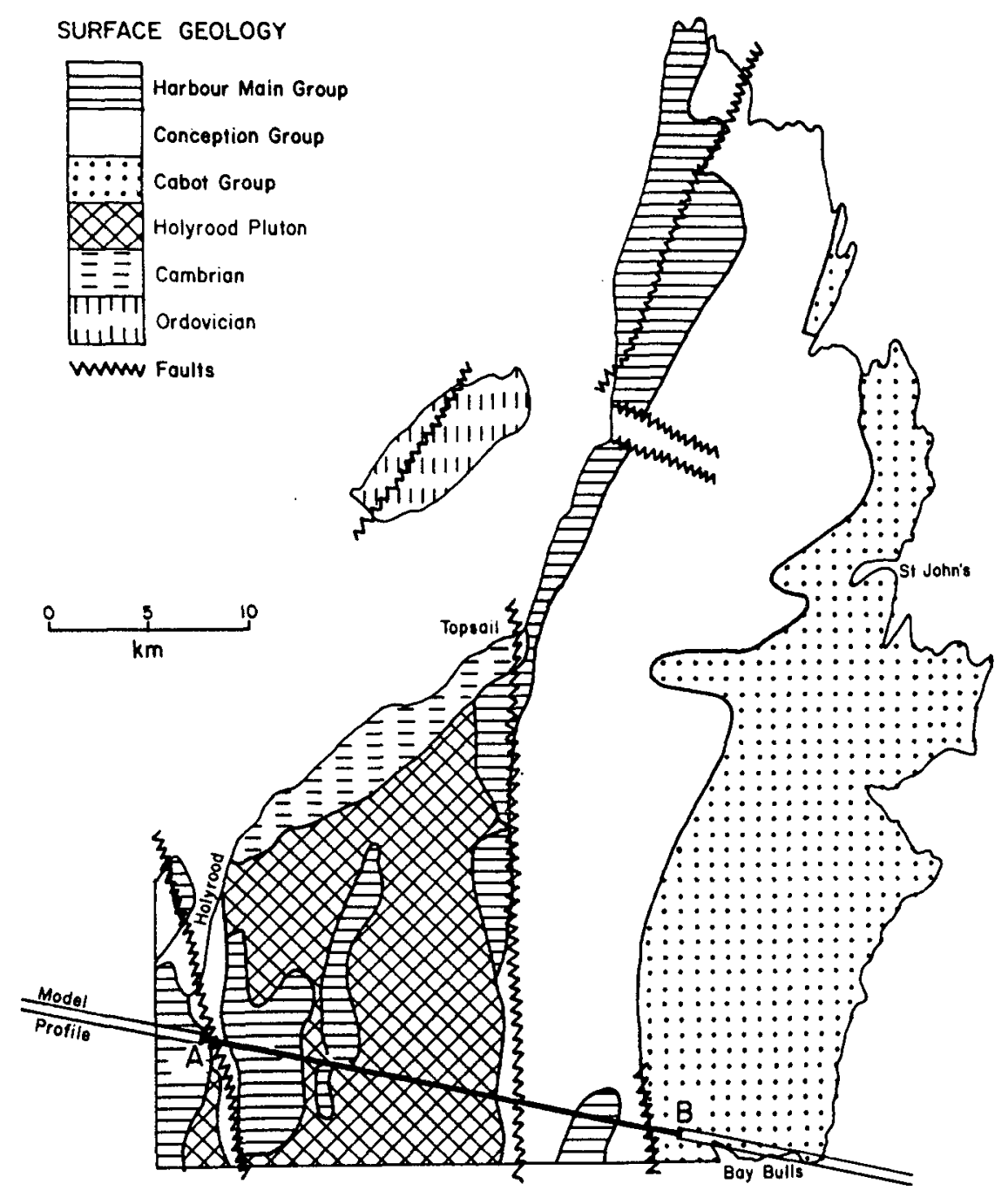

Fig. 1 - Generalized Geology of northeast Avalon Peninsula from Rose (1952), King (1980) and McCartney (1967).

bounded eastern margin of the pluton (Fig. 1). Sediments of the primarily siliceous volcaniclastic Conception Group overlie and are interbedded with the Harbour Main volcanics. The Conception Group rocks are considered to have been derived from the Harbour Main (Maher 1972).

The Conception Group sediments are in turn overlain by the Cabot Group (Rose 1952), renamed St. John's Group and Signal Hill Group (Williams and King 1979) on the basis of relationships in the southern portion of the Avalon and extended to the northern portion by King (1980). These rocks rest unconformably on the Conception Group from which Rose considers them to be derived. In general the thickness of the Cabot Group increases southward (King 1980).

\section{GEOPHYSICAL SETTING}

The Holyrood Pluton has been covered by the Dominion Observatory Gravity survey of Newfoundland (Weaver 1968) at 12 $\mathrm{km}$ spacing. Only four or five of these stations are in the vicinity of the pluton and the effect of the pluton is difficult to separate from the effect of a larger high which appears to be caused by Harbour Main type rocks to the southwest of the present survey area. Hodych and Weir (1972) report a gravity survey 
along the Trans Canada Highway along the northwestern edge of the pluton. Their interpretation of that profile suggests that the pluton is thin but no absolute thickness is given. Several subsequent gravity traverses have been conducted along the road between Holyrood and Bay Bulls and all concur with Hodych and Vieir's conclusion with actual results suggesting thicknesses less than $2.0 \mathrm{~km}$ for the pluton.

Aeromagnetic data for the area is available on the GSC $1: 63,360$ scale maps for St. John's, Holyrood and Bay Bulls. No interpretation of this data has been published.

\section{BOUGUER ANOMALIES}

Contour spacing of $20 \mathrm{um} / \mathrm{s}^{2}$
The data presented in this note have been collected from two sources. The gravity data were collected at $2.5 \mathrm{~km}$ spacing along existing roads as part of a project to determine the gravity field of the Avalon Peninsula. These data were reduced to Bouguer anomalies assuming a crustal density of $2.67 \mathrm{~g} \mathrm{~cm}^{-3}$ and the IGSN71 international gravity formula and base network. The resulting Bouguer anomalies for the area are shown in Fig. 2 . Since this Bouguer anomaly data exhibited a strong regional trend due to the thickening eastward sedimentary section with some perturbation in the vicinity of the Holyrood Pluton the regional

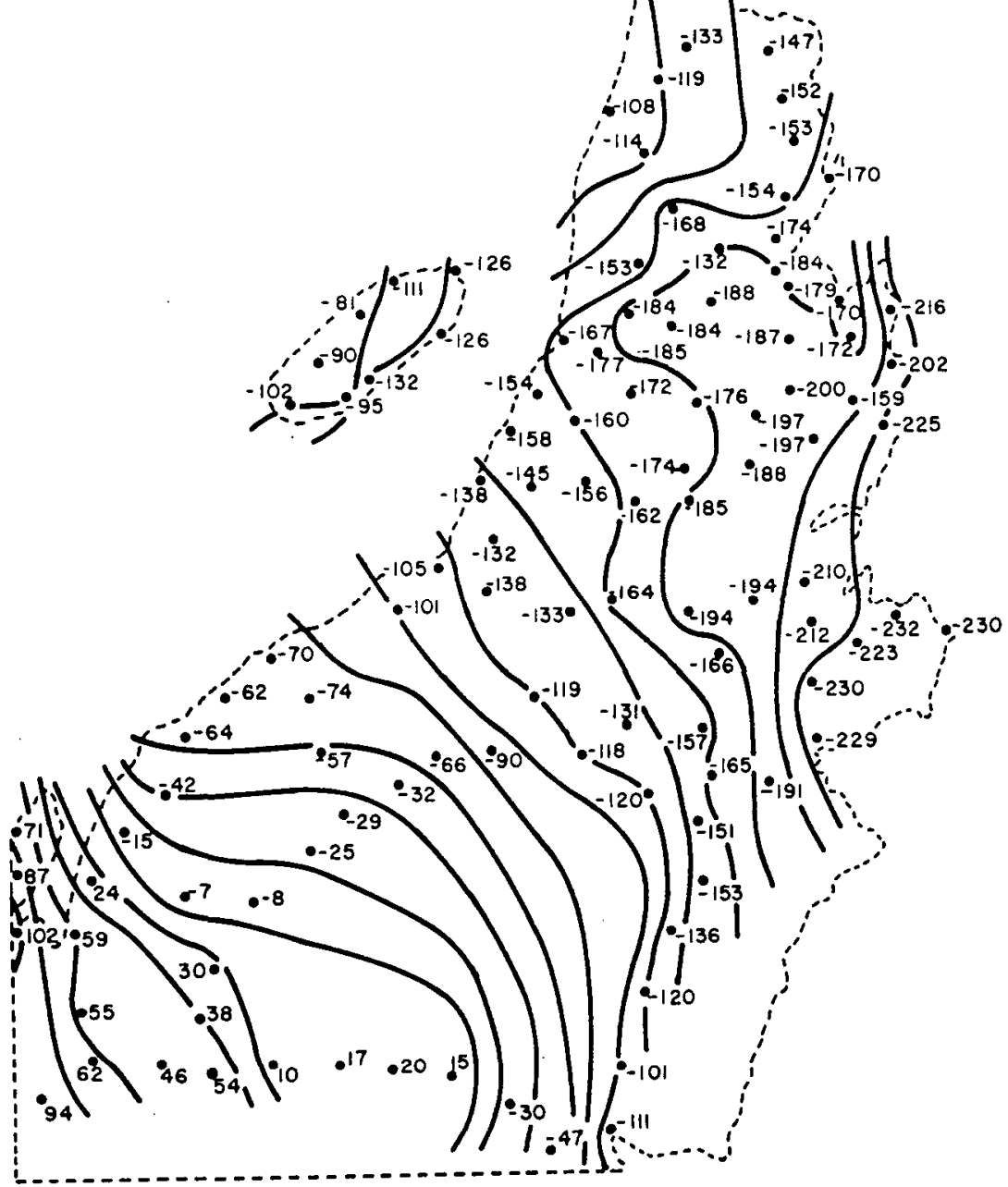

Fig. 2 - Bouguer gravity anomaly map for northeast Avalon. Peninsula. Bouguer anomalies in units of $\mu \mathrm{ms}^{-2}$ (0.1 mgals). Contour interval $20 \mathrm{\mu ms}^{-2}$ ( $\left.2.0 \mathrm{mgal}\right)$. 


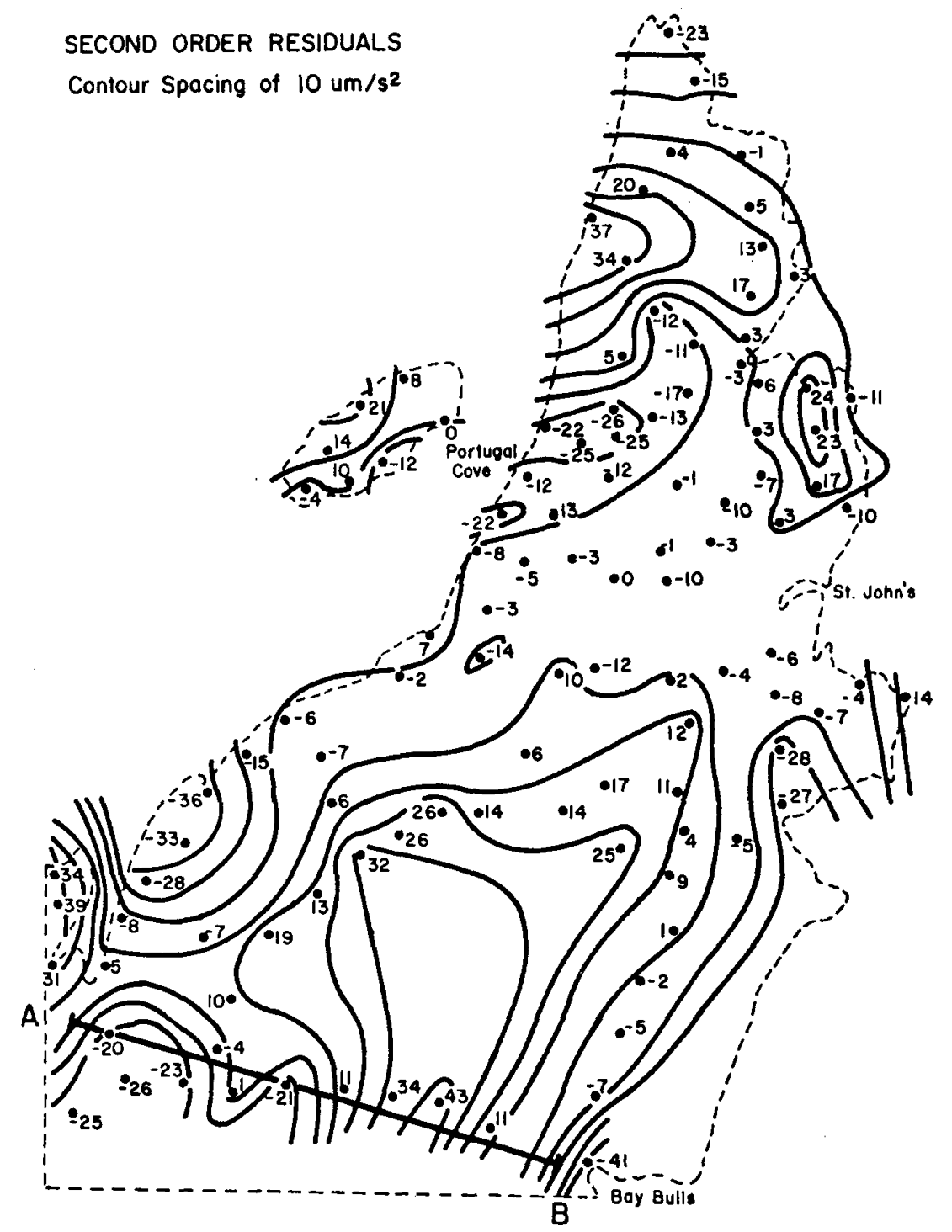

Fig. 3 - Residual gravity anomaly map for northeast Avalon Peninsula. Data for this map are obtained by removing a second order best fit surface from the data of Figure 2. Anomaly units same as Figure 2. Contour interval $10 \mathrm{\mu ms}^{-2}$ (1.0 mgal).

effect was removed by fitting a second order polynomial surface to the Bouguer anomaly data. The second order was chosen since it reduced the misfit from that of the first. order and was smoother than the fourth order. The resulting residual anomaly map is shown in Fig. 3 . These second order residual anomalies were used for the quantitative interpretation based upon the data long the profile shown (Figs, $1,2,3$ ). The magnetic data from the aeromagnetic maps were digitized at $0.5 \mathrm{mile}(0.8 \mathrm{~km})$ spacing and the IGRF 1965.0 was calculated by interpolation from IGRF (1971) published values. The resulting data were then reduced to a spacing of $4.0 \mathrm{~km}$ using an averaging procedure which computed the weighted average at the 25 data points surrounding the $4.0 \mathrm{~km}$ separated points. These data were then plotted and contoured at $25 \mathrm{nT}$ intervals (Fig. 4). 


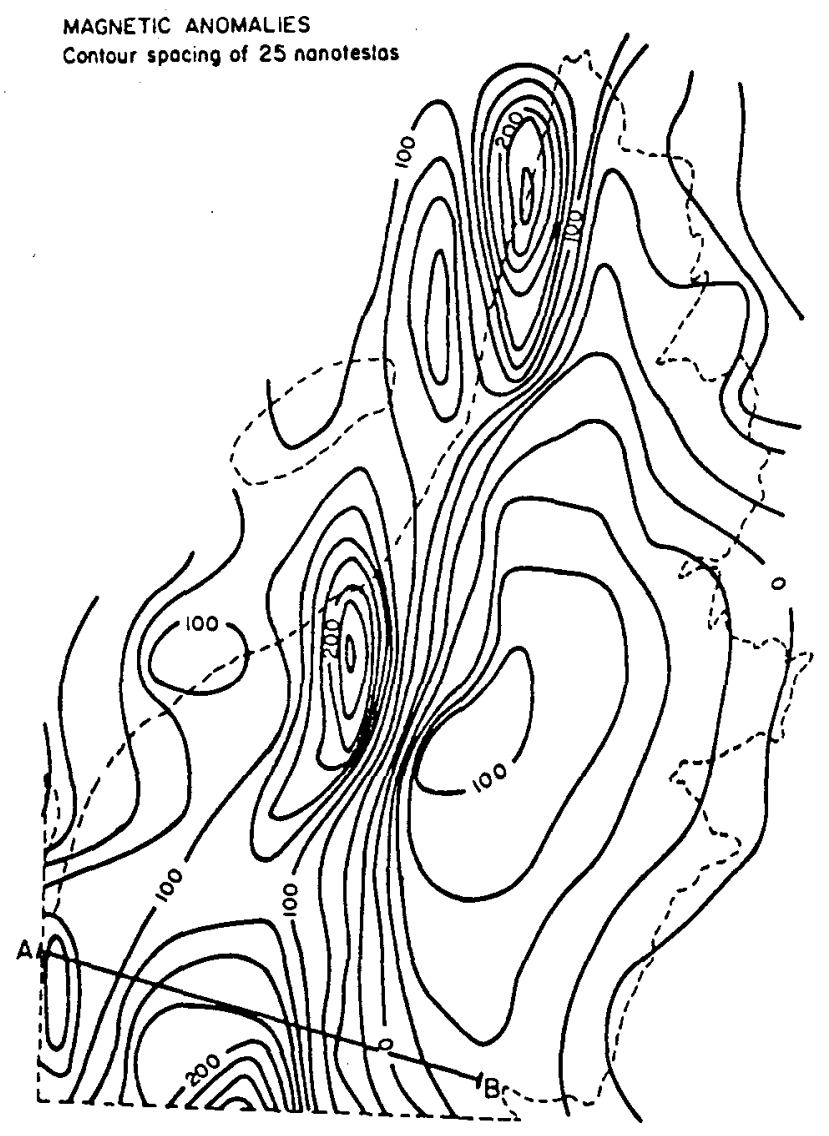

Fig. 4 - Total fiald magnetic anomaly map for the area formed by removing IGRF datum 1965.0 field from data points, applying smoothing filter, and contouring. Contour interval $25 \mathrm{nT}(25 \gamma)$.

\section{INTERPRETATION}

The Bouguer anomaly map, Fig. 2, shows a transition from negative to positive anomalies in the region of the eastern edge of the Holyrood Pluton. The second order residual map, Fig. 3, reveals an area of positive residual Bouguer anomalies along the eastern edge of the pluton followed westward by an area of negative residual anomalies and then a region of positive anomalies. The eastern region of positive anomalies continues northeastward. The region of negative anomalies coincides with the batholith and the eastern belt of positive anomalies correlates with exposed and inferred occurrences of Harbour Main volcanics depicted by Rose (1952).

This correlation of positive gravity anomalies with the mafic portion of the Harbour Main volcanics is reinforced by the magnetics (Fig. 4) where it is evident that the positive magnetic anomalies occur in a belt containing the batholith and the Harbour Main volcanics.

In order to use these correlations for modelling the residual gravity and the magnetics the densities and magnetic susceptibilities of representative rocks from each type were determined. The granites from the batholith consistently were low in density with a mean density of $2.58 \pm 0.03 \mathrm{~g} \mathrm{~cm}^{-3}$ determined from 8 samples. The outcrop in the area is limited but the samples are considered representative especially since the scatter is small. The magnetic susceptibility for the granite was determined to be $225 \times 10^{-6}$ cgs units. The surrounding sediments were found to have densities of $2.66 \pm 0.04 \mathrm{~g} \mathrm{~cm}^{-3}$ based upon 15 samples analysed. These sediments have insignificant magnetic susceptibilities $<50 \times 10^{-6} \mathrm{cgs}$. The properties of the volcanics varymore dramitically. The average density of the nine samples analysed initially was $2.68 \pm 0.12 \mathrm{~g} \mathrm{~cm}^{-3}$. A later collection of mafic volcanics all yielded densities of $2.79 \mathrm{~cm}^{-3}$ with susceptibilities $>2300 \times 10^{-6} \mathrm{cgs}$. In modelling, a density contrast of -0.09 $\mathrm{g} \mathrm{cm}^{-3}$ was used for the Holyrood granite, $+0.10 \mathrm{~g} \mathrm{~cm}^{-3}$ for the mafic volcanics and $-0.01 \mathrm{~g} \mathrm{~cm}^{-3}$ for the sediments with respect to $2.67 \mathrm{~g} \mathrm{~cm}^{-3}$, the normal crustal density.

The profile chosen for modelling (Figs. $1,3,4,5)$ is approximately perpendicular to the regional strike and crosses the middle of the pluton as depicted on geological maps of the area. Two dimensional modelling was used as the ratio of the length to the width of the pluton was $\sim 5: 1$. End effects would be small for such a $l / w$ ratio. The initial model was based upon Rose's (1952) geological profile CD which is in the same area. The subsurface structure was modelled to provide agreement with the geology from Rose (1952) and McCartney (1967) and with residual gravity anom- 

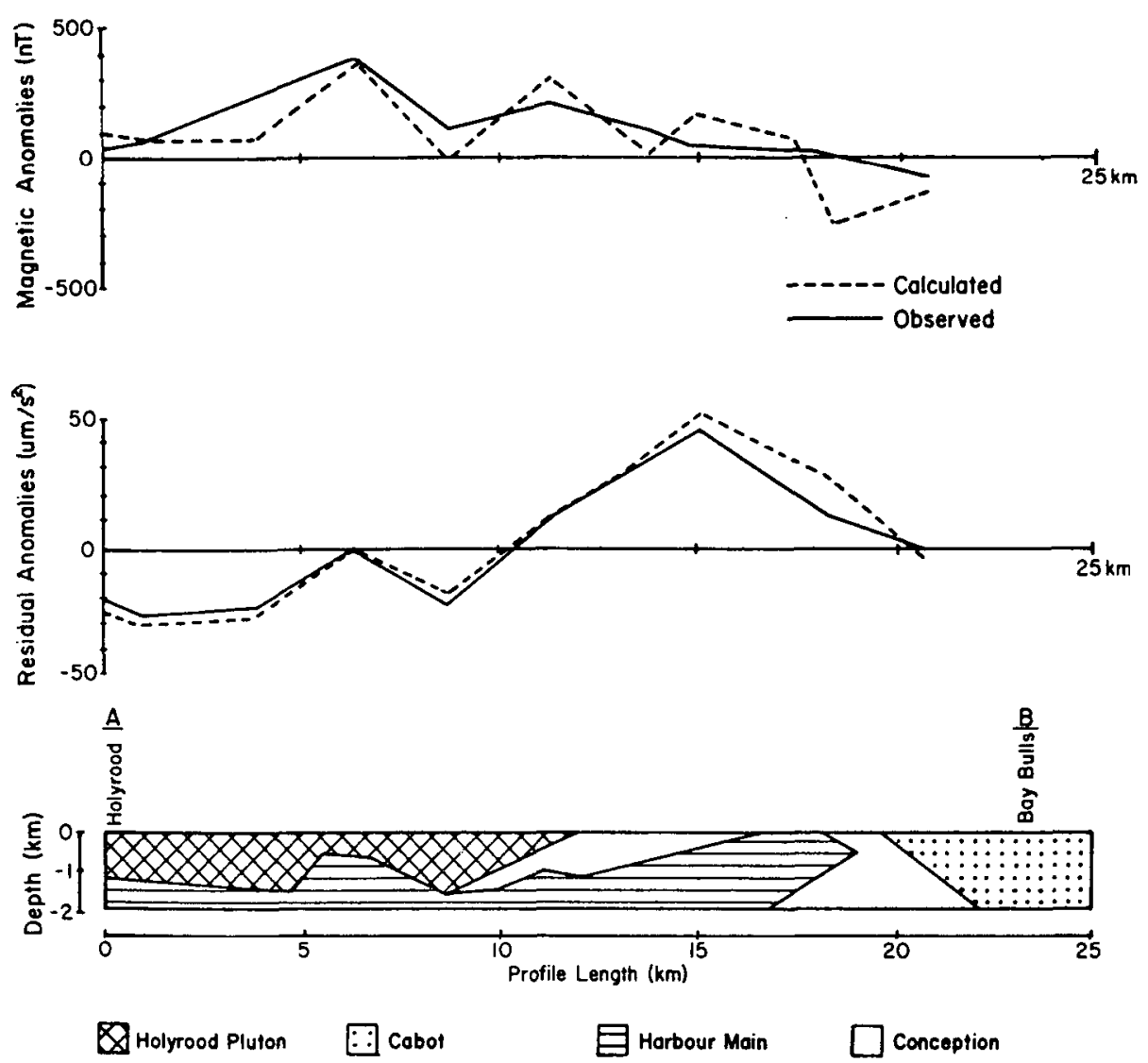

Fig. 5 - Model profile A A' showing fit of modelled -and observed - data. Data points are at points of inflection of straight line segment. Geological model shown below with same symbols as Figure 1 .

alies at the ten stations on the profile. The magnetic effect of the gravity model was then computed and adjustments made in the magnetic susceptibility and shapes. These shape adjustments were re-incorporated in the gravity model and the procedure continued until the model shown in Figure 5 was obtained. This model has an rms misfit of $5.6 \mathrm{\mu ms}^{-2}$ which is considered acceptable since the uncertainty in the Bouguer anomalies is $\pm 3.6 \mathrm{\mu m}^{-2}$. The misfit of the magnetic is more pronounced since a uniform magnetization of $6000 \times 10^{-6}$ cgs was used throughout the volcanics in the model. This susceptibility is approximately twice the average value of the susceptibilities determined from the samples, hence it may be argued that the susceptibility of the Harbour Main is not uniform or that remanent effects are present. However, the basic shape of the profile is evident from the magnetic data and the magnetics corroborate the need for having the mafic volcanics beneath the granite. It must also be recalled that the magnetic data used for the modelling are the result of an averaging process, hence they may be expected to vary less rapidly than the individual points output by the model calculation.

The model implies that the Holyrood Pluton is a relatively shallow feature. extending to a maximum depth of about $1.8 \mathrm{~km}$ below the surface. It is underlain throughout by the mafic portion of the Harbour Main volcanics. The gravity model also suggests that the mafic portion of the Harbour Main volcanics must exist in the subsurface beneath all the area in Figure 3 where the residual 
anomaly is positive i.e. beneath the Conception Group as far north as the Topsail-St. John's line. The negative residual gravity anomalies just north of Holyrood coincide with the granite in that area and indicate it may be thicker there than on the profile although one must note the presence of two screens of volcanics in this area as well.

\section{SUMMARY AND CONCLUSIONS}

The Holyrood granite is a relatively shallow pluton with a maximum thickness of $1.8 \mathrm{~km}$ based upon a density contrast of $-0.09 \mathrm{~g} \mathrm{~cm}^{-3}$. It is underlain to a depth of $2.0 \mathrm{~km}$ by material of positive density contrast and relatively high magnetic susceptibility. The mafic portion of the Harbour Main volcanics from the surrounding area have the required physical properties. On the basis of this, the mafic portions of the Harbour Main volcanics are also proposed to underlie the Conception Group sediments at least as far north as the TopsailCape Spear line. Known regions of outcrop of mafic Harbour Main correlate with the $200+n T$ magnetic anomalies on Fig. 4. This mafic material is restricted to the upper crust. Since the region east of the pluton has not been the subject of our interpretation one can but note that the density contrast of the sediments $\left(-0.01 \mathrm{~g} \mathrm{~cm}^{-3}\right)$ taken in conjunction with the regional gravity implies a large sediment thickness to the Cabot Group (St. John's and Signal Hill Groups) consistent with King's (1980) interpretation. The resolution of the model for the eastern portion awaits field studies offshore in 1982 .

\section{ACKNOWLEDGEMENTS}

The authors acknowledge with thanks the field assistance of $S$. Inkpen and P. McNicholas. Drs. V. S. Papezik and C.J. Hughes provided many of the samples analysed. Dr. A.F. King is thanked for numerous discussions regarding Avalon geology and for critically reading the manuscript. The financial support for this work came from NSERC in the form of a summer fellowship to DAP and through operating grant A7395 to HGM. Dr. R.T. Haworth and $M$. K. Seguin reviewed the manuscript and are thanked for their helpful suggestions.

HODYCH, J. P. and WEIR, H. C. 1972. A gravity survey across the Holyrood batholith of Newfoundland. Proceedings 24th International Geological Congress, Montreal (Abstract) p. 284.

HUGHES, C.J. 1970. The late Precambrian Avalonian orogeny in Avalon, southeast Newfoundland. American Journal of Science, 269, pp. 183-190.

HUGHES, C.J. and BRÜCKNER, W.E. 1971. Late Precambrian rocks of eastern AvaIon Peninsula, Newfoundland - a volcanic island complex. Canadian Journal of Earth Sciences, 8, pp. 899-915.

KING, A.R. 1980. The birth of the Caledonides: Late Precambrian rocks of the Avalon Peninsula, Newfoundland and their correlations in the AppalachianOrogen in Wones (ed.) Proceedings "The Caledonides in the USA" - IGCF Project 27, the Caledonide Orogen, 1979 Meeting, Blacksburg, Virginia, pp. 3-8.

MAHER, J. B. 1972. Stratigraphy and petrology of the Pouch Cove-Cape St. Francis Area, Newfoundland. Unpublished M.Sc. Thesis, Memorial University of Newfoundland, 75p.

McCARTNEY, W. D. 1967. Whitbourne Map Area, Newfoundland. Geological Survey of Canada, Memoir 341, 135p.

PAPEZIK, V.S. 1970. Petrochemistry of volcanic rocks of the Harbour Main Group, Avalon Peninsula, Newfoundland. Canadian Journal of Earth Sciences, 7, pp. 1485-1498.

1972. Late Precambrian ignimbrites in eastern Newfoundland and their tectonic significance. Proceedings 24 th International Geological Congress, Montreal, Section 1, pp. 147-152.

ROSE, E.R. 1952. Torbay Map Area, New- 
foundland. Geological Survey of Canada, Memoir 265, 64p.

STRONG, D. F. and MINATIDES, D.G. 1975. Geochemistry and tectonic setting of the late Precambrian Holyrood plutonic series of eastern Newfoundland. Lithos, 8, pp. 283-295.

WEAVER, D.F. 1968. Preliminary results of the gravity survey of the Island of Newfoundland with maps No. 53, 54, 55, 56, 57. Earth Physics Branch, Energy, Mines and Resources Canada, Ottawa.

WILLIAMS, H. and KING, A.F.: 1979. Trepassey Map Area, Newfoundland. Geological Survey of Canada, Memoir 389, $24 \mathrm{p}$. 